\title{
县 \\ STRATEGI MASYARAKAT NELAYAN DALAM PEMENUHAN KEBUTUHAN SUBSISTENNYA DI DESA WISATA PASIR PUTIH DALEGAN GRESIK
}

\author{
Yelly Elanda ${ }^{1}$, Azizah Alie $^{2}$ \\ ${ }^{1}$ Program Studi Sosiologi FISIP Universitas Wijaya Kusuma Surabaya \\ ${ }^{2}$ Program Studi Sosiologi FISIP Universitas Wijaya Kusuma Surabaya
}

Email :yelly.elanda@gmail.com | irwanto.azizah@yahoo.co.id

\begin{abstract}
Abstrak
Artikel ini akan berbicara tentang krisis subsistensi dan strategi yang dilakukan oleh masyarakat nelayan desa Dalegan untuk keluar dari zona subsisten. Hasil penelitian terdahulu telah menjelaskan terjadinya perubahan sosial ekonomi pada masyarakat desa Dalegan akibat dibukanya wisata pantai pasir putih. Namun kajian tersebut belum mengkaji kondisi masyarakat nelayan desa Dalegan secara khusus. Artikel ini mencoba untuk mendeskripsikan mengenai kondisi subsistensi yang dialami oleh para nelayan dan bagaimana strategi yang dilakukan oleh nelayan dalam memenuhi kebutuhan subsistensinya. Penelitian ini menggunakan metode kualitatif dengan pendekatan naratif melalui wawancara pada para nelayan di Desa Dalegan. Dari hasil penelitian menunjukkan bahwa masyarakat nelayan mengalami peningkatan secara ekonomi akibat dibukanya desa wisata pasir putih Dalegan. Namun masyarakat nelayan masih mengalami krisis subsistensi. Kondisi sulit yang dihadapi oleh para nelayan adalah kondisi alam yang kurang baik, modal yang kurang, sumber daya manusia yang rendah dan teknologi yang kurang mempuni. Strategi yang dilakukan oleh para nelayan untuk keluar dari zona subsisten yaitu dengan cara meminjam uang pada koperasi; meminta bantuan pada tetangga, kerabat dan juragan; anak dan istri turut bekerja dan nelayan beralih kerja ke sektor lain.
\end{abstract}

Kata Kunci : Masyarakat Nelayan, Krisis Subsistensi, Desa Wisata, Strategi Nelayan

\begin{abstract}
This article will talk about the subsistence crisis and the strategies undertaken by the fishing community of Dalegan Village to get out of the subsistence zone. The results of previous research have explained the occurrence of socio-economic changes in the Dalegan village community due to the opening of white sand beach tourism. However, that study has not specifically examined the condition of the Dalegan village fishing community. This article attempts to describe the subsistence conditions experienced by fishermen and how the fishermen's strategies are to meet their subsistence needs. This study uses a qualitative method with a narrative approach through interviews with fishermen in Dalegan Village. The results showed that the fishing community experienced an economic increase due to the opening of the
\end{abstract}




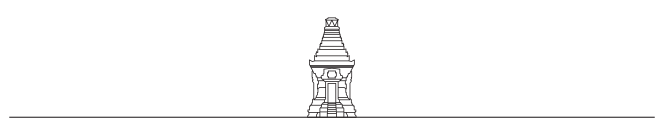

white sand tourism village of Dalegan. However, the fishing community is still experiencing a subsistence crisis. The difficult conditions faced by fishermen are unfavorable natural conditions, insufficient capital, low human resources and inadequate technology. The strategy undertaken by fishermen to get out of the subsistence zone is by borrowing money from cooperatives; asking for help from neighbors, relatives and bosses; children and wives also work and fishermen switch to work in other sectors.

Keywords : Fishermen Community, Subsistence Crisis, Tourism Village, Fisherman Strategy 


\section{PENDAHULUAN}

Indonesia dikenal sebagai negara maritim karena wilayahnya yang dikelilingi oleh laut bahkan mayoritas wilayah negara Indonesia merupakan perairan/kelautan. Dengan kekayaan laut yang dimilikinya maka tidak heran jika sebagian besar masyarakatnya mengandalkan hidup dari sektor kelautan. Masyarakat yang hidupnya bergantung pada hasil laut disebut sebagai masyarakat nelayan. Seperti yang dikatakan oleh Kusnadi bahwa secara geografis, masyarakat nelayan merupakan masyarakat yang hidup, tumbuh dan berkembang di kawasan pesisir dimana kawasan tersebut merupakan daerah transisi antara wilayah darat dan laut (Kusnadi, 2009). Dengan kekayaan laut yang melimpah tentunya masyarakat nelayan Indonesia bisa sejahtera dan berkembang menjadi masyarakat nelayan yang maju. Namun pada kenyatannya masyarakat yang tinggal dan mengandalkan alam sebagai penghidupannya tidak terlepas dari masalah sosial, ekonomi dan politik.

Masyarakat nelayan juga memiliki masalah yang harus dihadapinya, diantaranya adalah masalah kemiskinan, kesenjangan dan masalah ekonomi yang lainnya, akses modal, teknologi dan pasar yang terbatas, fungsi kelembagaan sosial ekonomi yang lemah, tingkat SDM yang rendah, kebijakan yang tidak berorientasi pada sektor kemaritiman dan sumber daya lingkungan yang mengalami degradasi (Kusnadi, 2006). Masalah-masalah yang telah diuaraikan tersebut tidak bisa berdiri sendiri, masalah itu saling terkait satu sama lain. Oleh karena itu diperlukan analisis untuk mengurai dan membahas permasalahan yang ada secara kompleks.

Masalah kemiskinan yang membelit masyarakat nelayan tentunya tidak bisa dilepaskan dari hubunganhubungan korelatif antara terbatasnya akses teknologi, modal, SDM yang rendah, fungsi lembaga sosial ekonomi yang tidak memadai, masalah lingkungan dan kebijakan pemerintah yang kurang berpijak pada masyarakat nelayan. Kondisi ini juga terjadi di kawasan wisata yang juga mengandalkan keindahan laut serta hasil laut yang menjadi tumpuan hidup nelayan, yaitu desa Dalegan. Desa Dalegan merupakan salah satu desa yang berada di kawasan pesisir utara pulau jawa. Secara administratif, desa Dalegan masuk dalam wilayah kecamatan Panceng kabupaten Gresik. Secara umum desa Dalegan merupakan desa yang masuk dlama kategori miskin dengan mengandalkan hidup dari alam yakni dari sektor pertanian dan kelautan.

Pada mulanya mayoritas masyarakat setempat bekerja sebagai petani dan nelayan. Namun kesulitan hidup, kurangnya lapangan kerja dan masalah ekonomi mendorong masyarakat untuk merantau ke luar negeri sebagai TKI. Mereka mencari peruntungan agar mampu keluar dari lingkar kemiskinan yang menjeratnya. Golongan usia produktif (25-29 tahun) yang berjenis kelamin laki-laki memilih untuk bekerja di luar negeri menjadi TKI di beberapa negara, diantaranya adalah Malaysia, Arab dan Brunei Darussalam. Namun mayoritas masyarakat Dalegan lebih banyak yang menjadi TKI di Malaysia. Para TKI yang sukses pulang dengan membawa hasil dari kerja mereka dan membangun rumah di kampung halamannya, maka bisa dilihat rumah yang ada di desa Dalegan besar-besar, arsitekturnya juga kekinian, dan banyak yang berlantai dua serta di garasinya terparkir mobil bahkan lebih dari satu mobil yang terparkir di rumahnya. Dengan keberhasilan itu maka banyak TKI yang akhirnya membawa saudara-saudaranya untuk menjadi TKI di negara yang sama. Banyaknya masyarakat yang bekerja sebagai TKI menyebabkan desa Dalegan dikenal sebagai desa TKI. Desa Dalegan merupakan desa yang memiliki jumlah presentase TKI tertinggi terhadap usia angkatan kerja di 
Kecamatan Panceng (Khumairoh, 2013).

Mayoritas masyarakat desa Dalegan bekerja sebagai TKI terutama laki-laki telah menyebabkan lahan pertanian menjadi terbengkalai. Secara visual bisa dilihat yang tinggal di rumah besar-besar tersebut mayoritas adalah perempuan dengan anak dan para orang tua yang ditinggal merantau ke luar negeri oleh para suaminya. Tenaga kerja yang bekerja di sektor pertanian mengalami penurunan yang cukup signifikan. Kondisi ini berbeda dengan sektor kelautan dimana para nelayan yang memutuskan untuk menjadi TKI cukup kecil. Berdasarkan data yang diperoleh, para TKI yang dulunya bekerja sebagai petani sebanyak $26 \%$ dan yang bekerja sebagai nelayan hanya 6\% (Khumairoh, 2013). Hal ini dikarenakan terbentuknya kawasan wisata pasir putih pantai Dalegan telah banyak memberikan kontribusi secara ekonomi bagi masyarakat nelayan Dalegan.

Terbukanya pantai Dalegan menjadi tempat wisata membawa angin segar bagi kaum nelayan setempat, mereka bisa menjual hasil lautnya kepada para wisatawan. Kawasan ini dikenal dengan ikan asap sebagai oleh-oleh khas pantai Dalegan. Warung yang berada di kawasan wisata juga turut menjual ikan asap sebagai suguhan kuliner yang utama. Harga yang murah meriah dan rasa yang enak karena kualitas ikan yang segar membuat para wisatawan puas menikmati sajian kuliner serta wisata yang disuguhkan di pantai Dalegan. Perubahan sosial yang terjadi pada masyarakat desa Dalegan yang sebelumnya merupakan masyarakat pertanian dan nelayan berubah menjadi desa TKI dan bertransformasi menjadi desa wisata dengan mengandalkan keindahan pantai Dalegan turut berpengaruh pada etika subsistensi nelayan dan petani yang ada di desa Dalegan. Perubahan sosial ini menyebabkan tercerabutnya struktur sosial yang ada pada masyarakat sehingga mempengaruhi relasi sosial dan ikatan patron klien yang ada pada masyarakat nelayan dan pertanian. Namun penelitian kali ini hanya akan fokus pada etika subsistensi dan pola hubungan patron klien masyarakat nelayan karena sampai pada hari ini masyarakat nelayan masih terus eksis dengan dibukanya pantai Dalegan menjadi kawasan wisata.

Historisitas masyarakat nelayan Dalegan yang berbeda dengan masyarakat nelayan yang lain menyebabkan peneliti tertarik untuk meneliti di daerah ini. Perubahan struktur masyarakat nelayan menjadi TKI kemudian secara kuantitas nelayan makin bertambah dengan adanya wisata pantai Dalegan bahkan mengalami polarisasi struktur kerja menjadi menarik untuk diteliti, terlebih menyangkut kondisi subsistensi masyarakat nelayan dan pola hubungan patron klien pada masyarakat nelayan. Penelitian ini akan mencoba untuk mengurai kondisi subsistensi masyarakat nelayan dengan dibukanya wisata pantai Dalegan dan mendeskripsikan hubungan patron klien diantara masyarakat nelayan sebagai katup penyelamat bagi para nelayan ketika mengalami kondisi sulit.

\section{TINJAUAN PUSTAKA STRUKTUR SOSIAL MASYARAKAT NELAYAN}

Masyarakat nelayan sangat bergantung pada hasil tangkapan atau budidaya hasil laut, mereka tinggal tidak jauh dari sumber penghidupannya yakni di pinggir laut. Hal ini sesuai apa yang dikatakan oleh Kusnadi bahwa nelayan merupakan sekelompok orang yang bermukim di pinggir pantai dan mengandalkan hasil laut untuk memenuhi kebutuhan hidupnya dengan cara melakukan penangkapan atau budi daya (Kusnadi, 2009). Sastrawidjaya juga memiliki pandangan yang sama mengenai definisi nelayan. Menurutnya nelayan ialah seseorang yang bermata pencaharian dari hasil laut dan pada umunya mereka tinggal di 
pesisir dan desa (Sastrawidjaya, 2002).

Masyarakat nelayan memiliki beberapa tipologi berdasarkan pada orientasinya dalam menangkap hasil laut. Ada empat tipe kelompok nelayan diantaranya adalah nelayan subsisten dimana nelayan ini menangkap ikan hanya untuk memenuhi kebutuhan sehari-hari. Nelayan komersil merupakan nelayan yang menangkap ikan untuk mendapatkan keuntungan, baik berukuran kecil maupun dalam jumlah besar, dipasarkan secara domestik maupun diekspor. Jenis nelayan ketiga adalah nelayan asli yaitu nelayan yang menangkap ikan untuk memenuhi kebutuhannya namun juga berhak memperoleh keuntungan meski dalam jumlah kecil. Yang terakhir adalah nelayan rekreasi dimana nelayan tersebut melakukan penangkapan ikan hanya demi kesenangan atau olahraga (Widodo dan Suadi, 2006).

Dalam struktur masyarakat nelayan sendiri, terdapat pembagian berdasarkan pada kepemilikan sumber daya ekonomi seperti modal dan alat tangkap ikan. Menurut Kinseng (Kinseng, 2014), struktur sosial masyarakat nelayan terdiri dari:

1. Pandega atau buruh nelayan

Buruh nelayan ikut dalam pengoperasian alat tangkap dan mereka diberi pendapatan berdasarkan pada pembagian hasil tangkapan ikan. Pandega ikut bekerja pada juragan tertentu yang diikat dengan sejumlah uang tertentu atau pemenuhan kebutuhan lainnya sebagai bentuk ikatan kerja atau penegasan posisi.

2. Nelayan kecil

Nelayan yang memiliki buruh sebanyak satu hingga 3 orang namun terkadang nelayan ini juga bekerja seorang diri untuk menangkap ikan karena modal yang dimiliki juga kecil

3. Nelayan menengah atau sedang

Nelayan jenis ini memiliki enam atau sembilan pekerja atau buruh, modal yang dimiliki untuk pengoperasian tangkap ikan tergolong sedang sehingga menggunakan perahu yang cukup besar dengan dua buah mesin.

4. Nelayan besar atau kapitalis

Nelayan kategori ini memiliki perahu dalam ukuran besar dengan lampu-lampu yang cukup mahal serta mesin yang digunakan dalam kapasitas besar berjumlah dua mesin. Nelayan ini memiliki 9-11 orang pekerja atau buruh

5. Nelayan kelas pemodal

Nelayan ini adalah kelas pemodal yang disebut dengan julukan tauke atau bakul dalam bahasa lokal. Para pembali ikan yang dinamakan makelar atau penyambung juga termasuk dalam kategori ini.

Masyarakat nelayan juga bisa dikategorisasikan berdasarkan pada karakteristik usaha sebagaimana digambarkan oleh Arif Satria.

\begin{tabular}{|c|c|c|c|}
\hline \multicolumn{4}{|c|}{$\begin{array}{l}\text { Tabel } 1 \text { : Penggolongan nelayan } \\
\text { berdasarkan karakteristik usaha }\end{array}$} \\
\hline Jenis & $\begin{array}{l}\text { Orientasi ekonomi } \\
\text { dan pasar }\end{array}$ & Tingkat teknologi & $\begin{array}{l}\text { Hubungan } \\
\text { produksi }\end{array}$ \\
\hline Usaha tradisional & $\begin{array}{l}\text { Subsisten, rumah } \\
\text { tangga }\end{array}$ & Rendah & $\begin{array}{l}\text { Tidak hierarkis, } \\
\text { status terdiri dari } \\
\text { pemilik dan ABK } \\
\text { yang homogen }\end{array}$ \\
\hline $\begin{array}{l}\text { Usaha post } \\
\text { tradisional }\end{array}$ & \begin{tabular}{|lr} 
Subsisten, & \\
surplus, & rumah \\
tangga, & pasar \\
domestic &
\end{tabular} & Rendah & $\begin{array}{l}\text { Tidak hierarkis, } \\
\text { status terdiri dari } \\
\text { pemilik dan ABK } \\
\text { yang homogeny }\end{array}$ \\
\hline Usaha komersil & $\begin{array}{l}\text { Surplus, pasar } \\
\text { domestic, ekspor }\end{array}$ & Menengah & $\begin{array}{lr}\text { Hierarkis, status } \\
\text { terdiri r } \\
\text { pemilik, manajer, } \\
\text { dan ABK yang } \\
\text { heterogen }\end{array}$ \\
\hline Usaha industri & Surplus, ekspor & Tinggi & $\begin{array}{lr}\text { Hierarkis, status } \\
\text { terdiri } & \text { dari } \\
\text { pemilik, manajer, } \\
\text { dan ABK yang } \\
\text { heterogen }\end{array}$ \\
\hline \multicolumn{4}{|c|}{ Sumber: (Satria, 2002:30) } \\
\hline
\end{tabular}




\section{ETIKA SUBSISTENSI MASYARAKAT NELAYAN}

Pada umunya subsistensi diartikan sebagai cara hidup minimalis yakni hanya sekedar hidup. Menurut Clifton R. Warthon subsistensi dibedakan menjaid dua yakni subsistensi produksi dan subsistensi hidup. Subistensi hidup yakni hanya sekedar hidup secara minim, sedangkan subsistensi produksi mempunyai karakteristik komersialisasi dan moneterisasi yang rendah (Wharton, 1963). Ciri khas dari perilaku ekonomi kehidupan nelayan karena mereka merupakan unit konsumsi sekaligus unit produksi. Agar bertahan sebagai suatu unit maka suatu keluarga harus memenuhi kebutuhan konsumsi secara subsisten yang tidak bisa dikurangi lagi dan tergantung pada jumlah keluarga yang dimiliki.

Konsep subsistensi dalam kehidupan masyarakat nelayan dimaknai sebagai suatu kondisi dimana nelayan tidak mampu memenuhi kebutuhan pokoknya untuk kehidupan sehari-hari karena mereka mendapatkan pendapatan yang rendah. Kondisi ini disebut dengan krisis subsistensi dimana nelayan tidak lagi dapat memenuhi kebutuhannya bahkan untuk makan dengan menggunakan bahan pangan yang utama. Strategi yang dilakukan agar petani subsisten dapat bertahan hidup menurut Scott adalah dengan mengencangkan sabuknya, swadaya dengan anggota keluarga (dibantu dengan keluarga, teman dan tetangga untuk mengatasi masa sulitnya), ikatan patron klien sebagai asuransi sosial, jaringan dan lembaga luar sebagai peredan kejutan di masa krisis, yang terakhir adalah bantuan dari negara (Scott, 1994).

\section{METODE}

Penelitian ini menggunakan metode kualitatif dengan pendekatan naratif. Strategi penelitian ini berusaha menyelidiki kehidupan individu-individu dengan meminta mereka dan sekelompok orang untuk menceritakan kehidupannya. Peneliti menceritakan kembali informasi yang didapat secara naratif (Creswell, 2017). Pada akhir tahap penelitian, peneliti menggabungkan pandangannya tentang kehidupan partisipan dengan pandangan peneliti secara naratif (Clandinin dan Connelly, 2000). Metode ini dipilih karena sesuai dengan tujuan dari penelitian dimana penelitian ini berusaha untuk mendeskripsikan atau menceritakan kembali mengenai kondisi subsistensi yang dihadapi oleh masyarakat nelayan Dagelan dan pola hubungan patron klien diantara masyarakat nelayan Dalegan agar mereka bisa selamat dari krisis subsistensi.

Penelitian ini dilakukan di desa Dalegan kecamatan Panceng kabupaten Gresik. Lokasi ini dipilih karena memiliki keunikan dibandingkan dengan lokasi yang lain. Perubahan sosial budaya dan konteks sosial budaya yang ada pada desa ini menarik perhatian peneliti untuk melakukan penelitian di sini. Desa Dalegan lebih dikenal sebagai desa TKI namun pada tahun 2007 desa ini menjadi desa wisata dengan mengandalkan keindahan alam pantainya. Kondisi ini menyebabkan polarisasi tenaga kerja yang ada pada masyarakat nelayan. Oleh karena itu dengan berbagai perubahan sosial yang terjadi maka peneliti ingin mengkaji kondisi subsistensi masyarakat nelayan di era pantai Dalegan sebagai daerah wisata. Kemudian peneliti juga ingin menggambarkan pola hubungan patron klien pada masyarakat nelayan yang makin terdekomposisi akibat dinobatkannya pantai Dalegan menjadi wisata.

Peneliti mengumpulkan data melalui wawancara secara mendalam kepada informan yang telah ditetapkan kriterianya. Peneliti menentukan subjek penelitian secara purposive yakni masyarakat nelayan sesuai dengan struktur kelas yang ada di desa Dalegan. Peneliti juga melakukan observasi secara langsung untuk mengamati kondisi 
subsistensi dan pola hubungan patron klien yang terjalin pada masyarakat nelayan. Peneliti juga menggunakan data sekunder berupa hasil penelitian terdahulu serta berbagai literatur atau referensi yang berkenaan dengan kondisi sosial budaya masyarakat desa Dalegan terutama masyarakat nelayannya, hubungan patron klien dan etika subsistensi masyarakat nelayan. Dalam melakukan analisis data, peneliti menggunakan metode interaktif. ada tiga komponen dalam melakukan analisis data ini yakni reduksi data, penyajian data dan penarikan kesimpulan (Miles dan Huberman, 1994).

\section{PEMBAHASAN \\ KONDISI SOSIAL EKONOMI MASYARAKAT DALEGAN}

Desa Dalegan dikenal dengan beberapa sebutan, namun akhir-akhir lebih dikenal sebagai desa wisata dan desa TKI. Sebelumnya, desa Dalegan adalah sebuah desa yang mengandalkan sumber daya alam untuk mencukupi kebutuhannya. Hamparan tanah pertanian yang luas $(29,63 \%$ dari wilayah desa Dalegan) dan daerah pesisir yang dekat dengan lokasi pelelangan ikan menyebabkan para penduduk desa banyak bekerja sebagai petani dan nelayan. Dengan penghasilan sebagai petani dan nelayan yang tidak menentu dan tidak dapat mencukupi kebutuhannya maka para penduduk dengan usia produktif banyak yang memutuskan untuk menjadi TKI di Malaysia. Mereka lebih memilih merantau di luar negeri karena pendapatan yang dihasilkannya lebih besar. Malaysia menjadi tujuan utama mereka untuk bekerja karena jarak tempuh yang lebih dekat dibandingkan dengan negara lain. Selain itu alasan budaya dan bahasa yang sama juga turut mendukung mereka lebih memilih bekerja di Malaysia. Namun alasan yang paling utama adalah karena di Malaysia terdapat banyak sanak saudara yang juga turut bekerja di sana. Sistem jemput saudara ketika para perantau pulang dan membawa saudaranya bekerja di Malaysia menjadi TKI menyebabkan masyarakat desa Dalegan banyak bekerja di Malaysia.

Jumlah persentase penduduk desa Dalegan yang bekerja sebagai TKI menempati posisi tertinggi di kecamatan Panceng (Khumairoh, 2013). Oleh karena itu desa Dalegan dikenal sebagai desa TKI. Penduduk desa Dalegan yang berjenis kelamin laki-laki dengan usia 25-29 tahun, berstatus kawin lebih berani untuk memutuskan menjadi TKI di Malaysia. Hal itu terjadi karena pada usia tersebut keinginan untuk memperbaiki taraf hidup keluarga semakin meningkat dan laki-laki sebagai kepala keluarga bertanggung jawab untuk memenuhi kebutuhan keluarga dan menafkahinya. Mayoritas yang bekerja sebagai TKI adalah para penduduk desa Dalegan yang sebelumnya bekerja sebagai petani.

Penyumbang TKI kedua setelah masyarakat pertanian adalah masyarakat nelayan. Nelayan yang berpindah profesi sebagai TKI mencapai 6\%. Mayoritas masyarakat nelayan masih mempertahankan profesinya sebagai nelayan. Hal ini dikarenakan posisi geografis mereka yang dekat dengan pantai utara pulau jawa yang menjadi penghasil laut besar, dengan ombak yang landai. Lokasi mereka yang dekat dengan tempat pelelangan ikan dan penyuplai ikan ke daerah sekitar Gresik menjadi alasan pekerjaan nelayan masih terus eksis hingga saat ini. Namun hal ini kini diperkuat dengan menjadikan pantai Dalegan sebagai daerah wisata. Jumlah nelayan akibat pembukaan wisata pantai pasir putih Dalegan ini semakin meningkat namun mengalami polarisasi atau dekomposisi pada masyarakat nelayan.

Para TKI yang berusia di atas 50 tahun lebih memilih untuk kembali ke desanya karena mereka sudah memiliki cukup modal dari hasil tabungannya selama menjadi TKI untuk membuka usaha di 
desa Dalegan. TKI melihat peluang dan potensi dengan adanya penetapan pantai Dalegan sebaagi arena wisata. TKI yang telah memiliki modal menginvestasikannya dalam beberapa sektor. Salah satunya di sektor kelautan, para pensiunan TKI atau keluarga TKI menginvestasikannya dengan membeli perahu dan kapal untuk menangkap ikan. Ikan yang didapat dari hasil memancing atau penangkapan dijual kepada beberapa tempat diantaranya adalah para penjual ikan asap berbasis industri rumah tangga, pelelangan ikan, koperasi nelayan, warung nasi dan dijual langsung kepada para pengunjung wisata. Dibukanya wisata di desa Dalegan membuat hasil tangkapan para nelayan dikenal ke segala penjuru, saat ini desa Dalegan dikenal sebagai penghasil ikan asap sebagai menu andalannya. Maka dari itu, tidak sah rasanya jika berkunjung ke sana tanpa mencicipi olahan ikan asap dan membawa pulang ikan asap sebagai oleh-oleh. Berkembangnya desa Dalegan menjadi desa wisata turut mempengaruhi jumlah dan menjadikan struktur sosial masyarakat nelayan makin beragam. Masyarakat nelayan di desa Dalegan tidak hanya sekedar mencari ikan di laut dan menjualnya namun telah berkembang menjadi industri ikan asap rumahan yang bertujuan komersil.

Di sektor pertanian, para TKI yang sudah kembali ke desa juga turut menginvestasikan modal yang dimilikinya dengan menjadikan beberapa tanah pertanian sebagai café, minimarket, ruko, tambak dan lain sebagainya yang mendukung desa Dalegan menjadi desa wisata. Bahkan ada beberapa tanah pertanian yang dibiarkan tidak terurus tanpa ada tanaman produktif, yang ada hanyalah rumputrumput panjang yang mulai membentuk semak belukar. Tanah ini sepertinya akan disewakan atau dijual mengingat harga jual tanah makin tinggi sejak dibukanya wisata pantai Dalegan. Kisah suksesnya para TKI bisa dilihat dari beberapa bangunan rumah berlantai dua dan kendaraan yang terparkir di garasi rumah mereka. Rumah-rumah itu terlihat sepi karena penghuninya adalah orang-orang tua yang menjaga anak atau cucunya. Rumah-rumah besar itu hanya dihuni oleh beberapa orang, pemilik rumah sebenarnya banyak yang sedang merantau ke luar negeri menjadi TKI. Keramaian hanya berpusat pada sudut-sudut tertentu atau daerah yang dekat dengan wisata pantai pasir putih. Rumah makan, café dan minimarket serta pertokoan yang berjejer menggambarkan keramaian dan cepatnya perputaran uang di sini. Sayangnya yang berjualan di daerah wisata ini kebanyakan adalah para perantau yang berasal dari luar desa bahkan dari luar Gresik. Mereka menyewa ruko, café dan bekerja di sana untuk mendapatkan penghasilan dari ramainya kunjungan para wisatawan. Penduduk asli desa Dalegan hanya menyediakan tanah, café, ruko untuk disewa meskipun ada beberapa yang berjualan atau mengelola usahanya sendiri. Hal ini terjadi karena pesona kesuksesan menjadi TKI masih belum lepas dari masyarakat desa Dalegan.

\section{KONDISI SULIT YANG DIHADAPI PARA NELAYAN}

Nelayan yang hanya mengandalkan hasil tangkapan, mereka mengandalkan kebaikan yang diberikan oleh alam kepadanya di setiap hari, mereka berharap alam bersikap baik atau tidak mengganggunya untuk menangkap ikan dan alam akan memberikan hasil tangkapan yang melimpah kepadanya. Setiap hari nelayan pergi ke tengah laut dengan harapan akan mendapatkan hasil laut yang melimpah karena apa yang mereka dapatkan pada hari itu maka itulah yang digunakannya untuk memenuhi kebutuhannya. Jika mereka mendapatkan hasil yang sedikit maka terjadilah krisis subsitensi yakni kebutuhan minimal mereka tidak terpenuhi bahkan untuk makan saja mereka 
kesulitan. Kondisi-kondisi ini menyebabkan nelayan begitu rentan dengan krisis subsistensi dan hanya sekedar hidup untuk memenuhi kebutuhan subsistennya saja atau kebutuhan pokoknya. Berikut adalah paparan mengenai faktor-faktor yang menyebabkan masyarakat nelayan berada pada kondisi sulit.

\section{Gelombang Laut yang Tinggi}

Faktor utama yang tidak mampu dihadapi oleh nelayan ketika alam tidak bersikap baik pada mereka. Pada kondisi-kondisi tertentu nelayan terpaksa tidak melaut karena cuaca dan gelombang laut yang tidak bersahabat. Jika mereka menantang alam dengan melaut maka mereka justru akan membahayakan dirinya. Setiap bulannya juga ada hari dimana nelayan tidak pergi melaut karena kondisi alam yang tidak memungkinkan. Malam-malam pada bulan purnama para nelayan berada di daratan, mereka tidak melaut karena ikan tidak akan muncul ke permukaan. Jikalau mereka ke laut maka mereka tidak mendapatkan ikan. Pada bulan purnama para nelayan biasanya menggunakan waktunya untuk membetulkan perahu dan jaringnya.

Para nelayan akan berlibur melaut hingga kondisi gelombang stabil dan alam sudah membaik. Pada saat nelayan tidak melaut, ini menjadi hari-hari yang sulit bagi nelayan. Nelayan tidak dapat memenuhi kebutuhan sehari-hari dan tidak bisa membayar utang kepada tempula maupun koperasi. Biasanya gelombang pasang semacam ini terjadi ketika akan dimulainya musim penghujan, terkadang nelayan tidak bisa pergi melaut sekitar 3-4 bulan atau tergantung pada kondisi cuaca. Kondisi ini tidak bisa diprediksi, nelayan hanya akan berharap pada kebaikan alam. Pada kondisi normal, nelayan juga tidak mampu memprediksi hasil ikan yang ditangkapnya, terkadang nelayan mendapatkan hasil banyak terkadang pula sedikit. Kondisi-kondisi yang tidak menentu ini tidak bisa pemenuhan kebutuhan sehari-hari. Jadi bisa dibayangkan bagaimana kehidupan nelayan, di musim tangkap saja kebutuhan subsistennya belum tentu terpenuhi apalagi pada saat terjadi gelombang besar. Kondisi ini yang menyebabkan nelayan berada pada lingkaran kemiskinan.

\section{Tingkat SDM Nelayan yang Rendah}

Masyarakat nelayan merupakan masyarakat yang dikenal dengan pendidikannya yang rendah. Di Indonesia nelayan tergolong pekerjaan informal dimana tidak dibutuhkannya persyaratan khusus seperti keterampilan dan pengetahuan tertentu. Dengan demikian maka pengetahuan nelayan mengenai penangkapan ikan, managemen usaha hingga pengolahan dan pemasarannya pun masih sangat terbatas. Tingkat sumber daya manusia nelayan yang rendah berpengaruh terhadap penghasilan yang didapatkan. Kondisi sosial ekonomi masyarakat nelayan di Indonesia masih tergolong miskin atau tingkat kesejahteraannya rendah. Hal ini dikarenakan pembagian hasil dengan sistem upah harian juga turut menambah penderitaan nelayan karena mereka tidak bisa mengatasi masalah ekonomi di masa paceklik.

Menurut masyarakat, nelayan adalah pekerjaan yang bisa dilakukan tanpa harus menempuh pendidikan tinggi bahkan pengetahuan dan informasi dasar yang berkenaan dengan persiapan nelayan untuk melaut saja mereka tidak memahami. Pengetahuan akan informasi cuaca, arah angin, kecepatan angin, gelombang perairan dan lokasi persebaran ikan turut memperparah kondisi nelayan yang pada akhirnya tidak mampu memprediksi hasil tangkapan ikan yang diperolehnya. Padahal akses terhadap informasi ini bisa mencegah nelayan untuk menghadapi dan mengantisipasi bencana dan bisa menekan jumlah biaya produksi. Masyarakat nelayan yang berpendidikan rendah tentunya tidak bisa terlepas dari latar belakang sosial, budaya dan ekonomi masyarakat Dalegan. 
Keluarga nelayan tidak dapat menyekolahkan anaknya akibat masalah ekonomi sehingga anak-anak mereka dengan terpaksa harus membantu keluarga dengan cara bekerja di laut. Hal ini juga diperkuat dengan pandangan masyarakat bahwa untuk bekerja sebagai nelayan yang diperlukan adalah otot, kekuatan dan pengalaman. Menurut mereka hal itulah yang mempengaruhi kemampuan melaut mereka. Sumber daya manusia nelayan yang rendah terkait dengan pola pikir, mental, dan keterampilan yang dimilikinya sehingga membentuk sistem sosial budaya masyarakat nelayan. Hal ini yang menjadi sumber masalah kemiskinan masyarakat nelayan. Seperti yang dikatakan oleh Sudarso bahwa nelayan khususnya nelayan tradisional mempunyai ciri yang sama yakni kurang berpendidikan (Sudarso, 2008).

\section{Teknologi yang Digunakan Rendah}

Tingkat pendidikan masyarakat nelayan yang rendah menjadi salah satu faktor dalam penerimaan dan penggunaan teknologi pada penangkapan hingga pemasaran ikan. Padahal dengan mengandalkan teknologi, nelayan dapat pergi melaut dengan jarak tempuh yang jauh dan mampu bertahan lama di perairan. Penggunaan teknologi turut mendukung efektifitas dan efisiensi nelayan selama melaut, pengolahan hingga pemasarannya. Dengan demikian maka nelayan akan mendapatkan hasil yang optimal dari kegiatan melautnya. Masyarakat nelayan yang ada di desa Dalegan juga masih mengalami keterbatasan teknologi. Penggunaan alat tangkap atau jaring dan perahu yang digunakan masih sederhana. Dengan demikian maka nelayan tidak bisa jauh-jauh dari sekitar perairan pantai sehingga ikan yang ditangkapnya pun tidak maksimal. Selain itu ketergantungan pada musim sangat tinggi sehingga pada musim ombak, nelayan tidak bisa pergi melaut. Hal ini berpengaruh terhadap pendapat yang diperoleh nelayan. Agar pendapatan nelayan meningkat maka diperlukan modernisasi pada alat tangkap dan perahu yang digunakannya serta mengupgrade sumber daya manusia yang dimiliki oleh nelayan.

\section{Kekurangan Modal}

Faktor lain yang menghambat kesejahteraan masyarakat nelayan atau yang menyebabkan masyarakat nelayan Dalegan tidak mampu memenuhi kebutuhan subsistensinya karena kekurangan modal. Akses kredit atau pinjaman terhadap bank juga sulit didapatkan oleh para nelayan karena mereka tidak memiliki agunan. Kondisi ini biasanya dimanfaatkan oleh para rentenir yang ingin mengambil keuntungan. Para nelayan yang ingin meningkatkan produktivitasnya justru terjebak pada sistem bunga pinjaman yang tinggi. Selain itu, penjual ikan juga meminjamkan modal kepada nelayan dengan sistem ikatan penjualan ikan. Sistem ini tidak membantu nelayan namun justru menjebak nelayan dengan memberikan harga ikan yang lebih rendah dibandingkan dengan harga pasar.

Nelayan Masyarakat nelayan Dalegan memang memiliki lembaga koperasi nelayan. Namun sayangnya koperasi ini tidak bisa meminjamkan modal besar kepada nelayan. Koperasi ini hanya bisa memberikan pinjaman hanya untuk sekedar memenuhi kebutuhan hidup nelayan di masa paceklik dan nelayan membayarnya dengan cara mencicil dari haisl penjualan ikan kepada koperasi tersebut. Padahal yang dibutuhkan nelayan adalah akses terhadap modal yang dapat meningkatkan produktivitas nelayan. Nelayan yang tidak memiliki modal maka tidak bisa mengembangkan usahanya dan tidak dapat melakukan peningkatan pendapatan. Kondisi ini semacam lingkaran setan yang harus membelit nelayan. Nelayan dihadapkan pada kondisi-kondisi yang dapat menjebak nelayan dalam kemiskinan yang makin dalam. Sistem-sistem yang ditawarkan untuk penambahan modal 
dibungkus dengan sesuatu yang dianggap itu membantu namun justru menenggalamkan nelayan lebih dengan bunga dan harga jual ikan yang lebih rendah.

\section{STRATEGI NELAYAN DALAM PEMENUHAN KEBUTUHAN SUBSISTENNYA}

Kehidupan masyarakat nelayan Dalegan hanya mengandalkan hasil tangkapan ikan di laut. Kondisi alam yang tidak menentu turut mempengaruhi kehidupan mereka. Jika hasil tangkapan melimpah maka beruntunglah keluarga mereka dapat memenuhi kebutuhannya dengan layak. Jika tangkapan mereka sedikit pada hari itu maka para nelayan tidak dapat memenuhi kebutuhan keluarganya bahkan hanya sekedar memenuhi kebutuhan minimal atau sehari-hari saja tidak cukup. Kondisi semakin parah jika nelayan tidak bisa pergi melaut akibat gelombang air yang tinggi dan angina yang kencang, orang-orang menyebutnya badai. Dalam situasi yang sudah pasti, pada bulan purnama para nelayan biasanya tidak pergi melaut. Hal ini dikarenakan cahaya bulan yang terang membuat ikan-ikan tidak berenang ke permukaan laut, cahaya bulan mampu menembus hingga ke dasar laut. Pada kondisi ini nelayan tidak pergi melaut karena tidak ingin merugi, ongkos produksi tidak sebanding dengan hasil tangkapannya.

Kehidupan nelayan yang masih sangat bergantung pada nelayan akan rentan menghadapi goncangan-goncangan yang tidak bisa diprediksi. Kondisi yang demikian menyebabkan nelayan dan keluarganya hanya bisa memenuhi kebutuhan minimal, hanya untuk sekedar hidup. Kondisi ini disebut subsistensi, sebagaimana yang dinyatakan oleh Clifton R. Warthon bahwa subsistensi hidup berkaitan dengan tingkat hidup yang bersifat minimal hanya untuk sekedar hidup (Warthon, 1963). Kondisi yang sulit dan tidak dapat diprediksi menyebabkan nelayan sulit menerima pembaharuan, mereka cenderung hidup monoton sebagaimana mestinya karena ingin mnedahulukan selamat. Mereka lebih memilih pilihan yang selama ini telah dilakukannya dibandingkan mencoba hal baru. Hal ini dikarenakan nelayan lebih mendahulukan selamat atau safety first. James Scott mengatakan bahwa mereka yang hidup diambang batas subsistensi akan lebih mengutamakan keamanan atau keselamatan dan dapat diandalkan dibandingkan keuntungan yang diperoleh dalam jangka waktu yang panjang (Scott, 1994). Sikap seperti itu dalam ekonomi subsistensi disebut dengan mendahulukan selamat atau safety first. Dalam ketidakberdayaan nelayan menghadapi alam yang rentan dengan krisis subsistensi diperlukan strategi untuk tetap memenuhi kebutuhan subsistennya. Nelayan memiliki strategi khusus dalam mengatasi permasalahan ini sebagaimana yang diterangkan oleh Ali, strategi diartikan sebagai upaya atau tindakan penyesuaian untuk menghadapi situasi tertentu, tindakan yang dilakukannya melalui pertimbangan yang wajar. Strategi ini juga bisa diartikan sebagai siasat atau rencana yang disusun untuk mencapai suatu tujuan tertentu (Nurahman, 2009). Begitu juga dengan strategi bertahan hidup merupakan serangkaian tindakan yang dilakukan secara sadar oleh rumah tangga miskin (Resmi, 2005). Berikut adalah beberapa strategi yang dilakukan nelayan yang tergolong sebagai rumah tangga miskin dalam pemenuhan kebutuhan subsistennya

\section{Meminjam Uang pada Tetangga, Keluarga dan Juragan}

Ketidakpastian dan ketidakberdayaan nelayan karena beberapa faktor yang menderanya maka diperlukan strategi agar nelayan tetap dapat memenuhi kebutuhan sehari-harinya. Salah satunya 
dengan melakukan peminjaman kepada pihak-pihak tertentu. Sebagaimana hasil penelitian yang dilakukan oleh Deny bahwa berhutang merupakan jalan keluar yang biasanya dilakukan oleh keluarga nelayan untuk memenuhi kebutuhan sehari-harinya (Hidayati, 2000). Para nelayan biasanya akan berhutang pada pihak-pihak yang dapat mengeluarkannya dari zona subsisten. Pihak-pihak ini dianggap sebagai katup penyelamat bagi mereka. Mereka adalah keluarga terdekat, tetangga, dan patron atua juragannya. Keluarga terdekat membantu dengan memberikan bahan makanan atau uang agar bisa sedikit meringankan beban. Tetangga adalah katup penyelamat kedua setelah keluarga terdekat tidak bisa membantunya terlebih desa Dalegan merupakan desa TKI dimana mayoritas penduduknya bekerja di Malaysia. Kondisi ini mengakibatkan para nelayan cenderung meminta bantuan kepada tetangga jika dalam kondisi darurat. Tetangga dirasa lebih dekat dibandingkan dengan keluarga karena banyak keluarga yang sedang merantau ke luar negeri. Katup penyelamat yang lain adalah juragan atau patron yang memiliki status ekonomi yang lebih tinggi dan memiliki kuasa. Biasanya juragan akan memberikan bantuan uang dan para nelayan akan mencicilnya atau membayarnya dengan menjual hasil tangkapannya kepada juragan tersebut.

\section{Bekerja Sambilan di Tempat Lain}

Strategi kedua yang dilakukan oleh para nelayan desa Dalegan adalah dengan melakukan diversifikasi kerja. Diversifikasi kerja adalah strategi yang dilakukan oleh nelayan dengan menggabungkan kegiatan menangkap ikan dengan pekerjaan lain atau pekerjaan sampingan dan bisa dilakukan secara bergantian. Hal ini senada dengan hasil penelitian Deny yang menyatakan bahwa strategi adaptasi yang digunakan oleh nelayan antara lain dnegan diversifikasi kerja dan nafkah ganda (Hidayati, 2000). Dengan melakukan kegiatan lain, selain melaut para nelayan bisa mendapatkan penghasilan tambahan. Penghasilan dari beberapa pekerjaan ini diharapkan dapat memenuhi kebutuhan keluarganya. Hal ini membuktikan bahwa penghasilan utama sebagai nelayan masih belum mampu mencukupi kebutuhan rumah tangga nelayan. Diversifikasi kerja yang dilakukan oleh para nelayan bervariasi, ada yang memilih untuk bertani, ada yang bekerja sebagai buruh bangunan dan buruh tani. Pekerjaan sambilan apapun mereka lakukan, mau tidak mau mereka harus mencari kegiatan atau pekerjaan lain demi mendapatkan uang agar dapat memenuhi kebutuhan keluarganya, membayar hutang dan membiayai sekolah anaknya.

\section{Anak dan Istri Ikut Bekerja}

Kebutuhan subsisten yang tidak terpenuhi akibat penghasilan yang tidak menentu mendorong anggota keluarga nelayan yang lain turut bekerja. Mereka bekerja untuk menambah penghasilan keluarga, mengurangi beban suami atau kepala keluarga serta menyelamatkan keluarga dari krisis subsistensi yang dialaminya. Optimalisasi peran tenaga kerja anggota keluarga dalam mengatasi kemiskinan yang membayangi keluarga nelayan merupakan salah satu cara agar mereka bisa keluar dari garis kemiskinan. Cara ini juga digunakan oleh masyarakat pedesaan yang mengalami transisi dan golongan miskin di kota sebagaimana dikatakan oleh Harbinson dalam (Anindyasari, 2013) mengenai teori household survival strategy "Mereka akan memanfaatkan sumber-sumber yang tersedia bila kondisi ekonomi memburuk atau mengalami perubahan dengan cara memanfaatkan tenaga kerja keluarga.

Pengerahan tenaga kerja keluarga tidak hanya melibatkan istri namun juga anak-anak, pembagian kerjanya pun berdasarkan pada jenis kelamin. Anak laki-laki akan bekerja untuk membantu pekerjaan bapaknya yakni melaut atau memancing 
ikan di pantai. Sedangkan anak perempuan cenderung membantu pekerjaan ibunya seperti berjualan kue dan nasi di warung. Yang harus disadari adalah bekerja sebagai nelayan dan memiliki penghasilan tambahan masih belum cukup untuk memenuhi kebutuhan subsistennya. Pekerjaan istri nelayan bervariasi, ada yang menjual kue, nasi dan ikan asap untuk dijual kembali pada wisatawan, ada yang sebagai buruh tani dan ada yang bekerja sebagai pembantu di warung. Kondisi buruh nelayan dan nelayan kecil memang sangat rentan terhadap goncangan. Masyarakat nelayan yang ada di desa Dalegan ini masih tergolong sebagai buruh nelayan dan nelayan kecil sebagaimana dikatakan oleh Kinseng bahwa buruh nelayan bekerja pada juragan dan setiap harinya menggantungkan pendapatannya berdasarkan pada hasil tangkapan yang diperolehnya dan sistem pembagiannya dengan juragan adalah sistem bagi hasil. Nelayan Dalegan masih tergolong nelayan kecil karena mereka hanya memiliki 1-3 orang buruh bahkan mereka masih melaut sendirian (Kinseng, 2014).

\section{Meminjam Uang pada Koperasi}

Opsi terakhir yang bisa dilakukan oleh para nelayan adalah dengan meminjam uang pada koperasi. Di desa Dalegan ini terdapat koperasi nelayan. Koperasi ini didirikan agar masyarakat nelayan bisa mengakses modal, mengatasi situasi sulit di masa paceklik dan agar nelayan bisa berkembang lebih maju dengan mengolah dan memasarkan hasil tangkapannya. Koperasi ini tidak hanya menerima hasil tangkapan ikan para nelayan dan memberikan pinjaman kepada nelayan, namun koperasi ini juga terdapat kegiatan pemberdayaan untuk ibu-ibu nelayan dimana mereka mengolah hasil tangkapannya kemudian menjualnya kepada para wisatawan. Salah satu hasil olahan ikan yang terkenal dari desa Dalegan adalah ikan asap. Koperasi ini menjadi nafas baru atau harapan bagi para nelayan untuk keluar dari zona subsisten. Pada akhirnya ada harapan lebih besar lagi dengan adanya koperasi ini yakni bisa memberikan pinjaman yang lebih besar kepada nelayan terkait dengan pengadaan teknologi dan alat tangkap yang mempuni bagi nelayan agar dapat meningkatkan produktivitasnya.

\section{KESIMPULAN}

Pada umumnya masyarakat desa Dalegan mengalami peningkatan secara ekonomi dan kemajuan dalam pola pikir secara perlahan. Terbukanya akses informasi dan struktur sosial masyarakat desa Dalegan yang terbuka menyebabkan masyarakat Dalegan mampu menerima perubahan yang ada. Desa Dalegan mengalami beberapa decade perubahan, pertama perubahan dari masyarakat desa agraris dan maritim menuju pada masyarakat desa TKI dengan menyumbang jumlah angka TKI tertinggi di kecamatan Panceng Gresik. Para nelayan dan petani banyak yang beralih profesi sebagai TKI, namun jumlah penyumbang terbanyak berasal dari petani. Perubahan pada fase kedua yakni dibukanya kawasan pantai pasir putih Dalegan menjadi daerah wisata. Dalam perubahan kali ini masyarakat nelayan merasakan betul dampaknya. Masyarakat nelayan perlahan mulai bangkit dari kemiskinan. Namun kondisi masyarakat desa Dalegan masih berada pada nelayan subsisten dimana mereka masih kesulitan dalam memenuhi kebutuhan minimalnya atau hanya sekedar hidup.

Kemiskinan yang terjadi pada masyarakat nelayan Dalegan ini terjadi akibat adanya rantai yang membelit masyarakat Dalegan agar mereka tidak bisa keluar dari kemiskinan atau krisis subsistennya. Faktor-faktor yang menyebabkan nelayan berada pada krisis subsistennya adalah gelombang air laut yang tinggi, SDM yang 
rendah, teknologi yang digunakan kurang mempuni dan kurangnya modal yang dimiliki oleh nelayan. Keempat faktor ini saling terkait dan mempengaruhi. SDM yang rendah berpengaruh terhadap pengetahuan mengenai informasi, pengetahuan dan teknologi yang harus digunakan oleh nelayan untuk memperbarui alat tangkapnya. Kekurangan modal juga dipengaruhi oleh jumlah pendapatan yang dihasilkan oleh nelayan namun penghasilan yang dimiliki oleh para nelayan masih sedikit bahkan untuk menghidupi keluarganya masih kekurangan. Oleh sebab itu masyarakat nelayan Dalegan memiliki strategi dalam memenuhi kebutuhannya yakni bekerja sambilan di sektor lain, mengoptimalkan tenaga kerja dari anggota keluarga yang lain, meminta bantuan kepada orang terdekat yakni keluarga, tetangga dan juragannya serta yang terakhir adalah meminjan uang kepada koperasi. Koperasi ini merupakan wujud kemajuan masyarakat nelayan Dalegan karena melalui koperasi ini para nelayan bisa mengembangkan hasil produksinya dengan mengolah dan memasarkan ikan.

\section{DAFTAR PUSTAKA}

Anindyasari, Fitria. 2013. Anak Jalanan (Studi Deskriptif Anak Jalanan Bekerja Sebagai Penjual Koran di kota Surabaya). Surabaya: Fakultas Ilmu Sosial dan Ilmu Politik Universitas Airlangga.

Clandinin, D.J\&Connelly, F.M. 2000. Narrative Inquiry: Experience and Story in Qualitative Reseach. San Fransisco: Jossey-Bass.

Creswell, W Jhon. 2012. Research Design Pendekatan Kualitatif, Kuantitatif, dan Mixed. Yogyakarta: Pustaka Pelajar.

Hidayati, Deny. 2000. Isu Kemiskinan dan Degradasi Sumberdaya Laut. Laporan. Puslitbang Kependudukan dan Ketenaga- kerjaan Lembaga Ilmu Pengetahuan Indonesia (PPT-LIPI).

Khumairoh, Zahrotul. 2013. Kajian Tentang TKI Dari Desa Dalegan Kecamatan Panceng Kabupaten Gresik Ke Malaysia. Swara Bhumi e-Journal Pendidikan Geografi FIS UNESA vol 2 no 1 tersedia di https://jurnalmahasiswa. unesa.ac.id/index.php/swarabhumi/article/ view/81 diakses pada tanggal 13 Desember 2019.

Kinseng, A. Rilus. 2014. Konflik Nelayan. Jakarta: Yayasan Obor Indonesia.

Kusnadi. 2009. Keberdayaan Nelayan Dalam Dinamika Ekonomi Pesisir. Yogyakarta : Ar-Ruzz Media

Nurahman, Ali, 2009. Belajar dan Pembelajaran. Bandung : Alfabeta.

Resmi, Setia. 2005. Gali Tutup Lubang Itu Biasa: Strategi Buruh Menanggulangi Persoalan dari Waktu ke Waktu. Bandung : Yayasan Akatiga.

Satria, Arif, 2002. Pengantar Sosiologi Masyarakat Pesisir. Jakarta: Pustaka Cidesindo.

Scott, James. 1994. Moral Ekonomi Petani. Jakarta: LP3ES.

Sudarso.2008. Tekanan Kemiskinan Struktural Komunitas Nelayan Tradisional di Perkotaan. Jurnal Ekonomi: FISIP Universitas Airlangga Surabaya.

Wharton, C.R. Jr. 1963. Demographic Aspects of Subsistence Economics: Some Micro-Economic Problem. Singapore: Seventh International Conference On Planned Parenthood dalam Rosanti, Erni. 1990. Pengetahuan dan Lingkungan Subsistensi Kasus Petani Sayur di Dusun Mekarsari Kertasari Bandung tersedia di https://repository.ipb.ac.id/jspui/ bitstream/123456789/29330/2/A90ERO.f diakses tanggal 14 Desember 2019

Widodo J. dan Suadi. 2006. Pengelolaan Sumberdaya Perikanan Laut. Yogyakarta: Gadjah Mada University Press 